\title{
Struktur Komunitas Padang Lamun Di Perairan Gili Air, Lombok Utara
}

\author{
Ibadur Rahman $^{1 *}$, Nurliah ${ }^{1}$, Edwin Jefri $^{1}$, Chandrika Eka Larasati ${ }^{1}$ \\ ${ }^{1}$ Program Studi Ilmu Kelautan, Jurusan Perikanan dan Ilmu Kelautan, \\ Fakultas Pertanian, Universitas Mataram \\ *ibadur.rahman@unram.ac.id
}

\begin{abstract}
Seagrass is a coastal ecosystem that has important role as a feeding ground, a spawning ground and a nursery ground for various marine biota. This study aims to examine the biodiversity of seagrass at Gili Air, North Lombok Regency, West Nusa Tenggara. This study was conducted to observe the cover percentage of seagrass, it's composition, the number of seagrass stands, canopy's height, frequency of seagrass presence, and index of importance of seagrass. Seagrass data was collected using a $50 \mathrm{~cm} \times 50 \mathrm{~cm}$ quadrant transect, with a total area of $100 \mathrm{~m}^{2}$, referring to the monitoring standards set by SeagrassNet. Water quality analysis was carried out at the Bioecology Laboratory of the Aquaculture Study Program, University of Mataram, and at the Laboratory of the Marine Aquaculture Center (BPBL) of Sekotong, West Lombok. The results showed that the seagrass communities in Gili Air waters were composed of 5 (five) species: Halophila ovalis, Thalassia hemperichii, Cymodocea rotundata, Halodulea pinifolia, and Halodule uninervis, with the percentage of coverage ranging from 26.88-39.17\%, and the average coverage by $31.53 \%$. Thalassia hemperichii is the species that has the highest contribution to the seagrass community at Gili Air.
\end{abstract}

Keywords: community, contribution, Thalassia hemperichii

\section{PENDAHULUAN}

Padang lamun merupakan salah satu ekosistem pesisir yang memiliki peranan penting, khususnya bagi kelangsungan hidup biota perairan yang berasosiasi dengannya. Biota-biota tersebut memanfaatkan lamun sebagai tempat mencari makan (feeding ground), tempat melakukan pemijahan (spawning ground) dan daerah pembesaran (nursery ground) (Yunita et al., 2020). Selain memiliki peranan terhadap kelangsungan hidup biota, padang lamun juga memiliki peran penting lainnya, yaitu sebagai sebagai perangkap sedimen perairan (Riniatsih et al., 2018); peredam gelombang (Rustam et al., 2019) pendaur ulang zat hara (Rustam et al., 2015) dan sebagai penyerap sejumlah besar karbon dari atmosfer yang lebih umum disebut dengan istilah karbon biru (blue cabon) (Rustam et al., 2019).

Ekosistem padang lamun mendapatkan tekanan yang terus menerus, baik secara alami maupun karena adanya campur tangan manusia, terutama yang tinggal dan beraktifitas di kawasan pesisir (Rahmawati et al., 2014). Hal tersebut mengakibatkan terjadinya penurunan atau degradasi padang lamun (Setiawan et al., 2012; Riniatsih et al., 2018) yang cukup signifikan. Syafrie et al. 
(2018) menyebutkan bahwa dalam kurun waktu 40 tahun terakhir telah terjadi degradasi lamun sebesar $58 \%$.

Terjadinya penurunan atau degradasi padang lamun semakin mengkhawatirkan mengingat kurangnya perhatian dan pengawasan pemerintah serta rendahnya kesadaran masyarakat untuk mempertahankan kelestarian ekosistem lamun (Rahman \& Astriana, 2019; Rahman et al., 2020). Masyarakat dan para stakeholder harus senantiasa dilibatkan dalam upaya pelestarian ekosistem lamun, sehingga laju degradasi lamun dapat dihentikan, dan upaya rehabilitasi lamun semakin masif dilakukan untuk mengembalikan kondisi lamun sebagaimana mestinya.

Gili Air merupakan salah satu pulau di Kecamatan Pemenang, Kabupaten Lombok Utara, dimana masyarakatnya memiliki aktivitas antara lain sebagai nelayan pancing, nelayan tangkap (menggunakan perahu), pengendara transportasi wisata antar pulau, dan pelaku usaha. Disamping itu, terdapat pula rumah-rumah penduduk yang cukup padat, dimana sebagiannya tidak memiliki sarana pengelolaan limbah yang memadai, sehingga sejumlah limbah domestik dibuang ke laut. Limbah buangan tersebut berpotensi mengurangi kualitas perairan, sehingga dapat mengganggu kelangsungan hidup biota perairan dan kelestarian lingkungan perairan, khususnya pada ekosistem lamun.

Penelitian ini bertujuan untuk mengkaji struktur komunitas padang lamun di Gili Air, Kecamatan Pemenang, Kabupaten Lombok Utara. Struktur komunitas lamun dapat menggambarkan kondisi kesehatan padang lamun, apakah termasuk dalam kategori sehat, kurang sehat, atau kategori miskin, sebagaimana yang ditetapkan dalam standar monitoring ekosistem lamun (Syafrie et al., 2018). Kondisi kesehatan lamun tersebut dapat digunakan sebagai bahan pertimbangan para stakeholder dalam membuat kebijakan terkait penataan dan pemanfaatan kawasan perairan yang berdampak terhadap ekosistem perairan, khususnya lamun.

\section{METODE PENELITIAN}

Penelitian ini dilaksanakan pada Juli - Oktober 2021 di kawasan padang lamun perairan Gili Air, Kecamatan Pemenang, Kabupaten Lombok Utara, Provinsi Nusa Tenggara Barat, meliputi pengamatan secara langsung (in situ) kondisi padang lamun di lapangan, pengukuran nilai parameter kualitas perairan di Balai Perikanan Budidaya Laut (BPBL) Lombok, serta kegiatan pengolahan dan analisis data yang dilakukan di kampus Program Studi Ilmu Kelautan, Jurusan Perikanan dan Ilmu Kelautan, Fakultas Pertanian, Universitas Mataram.

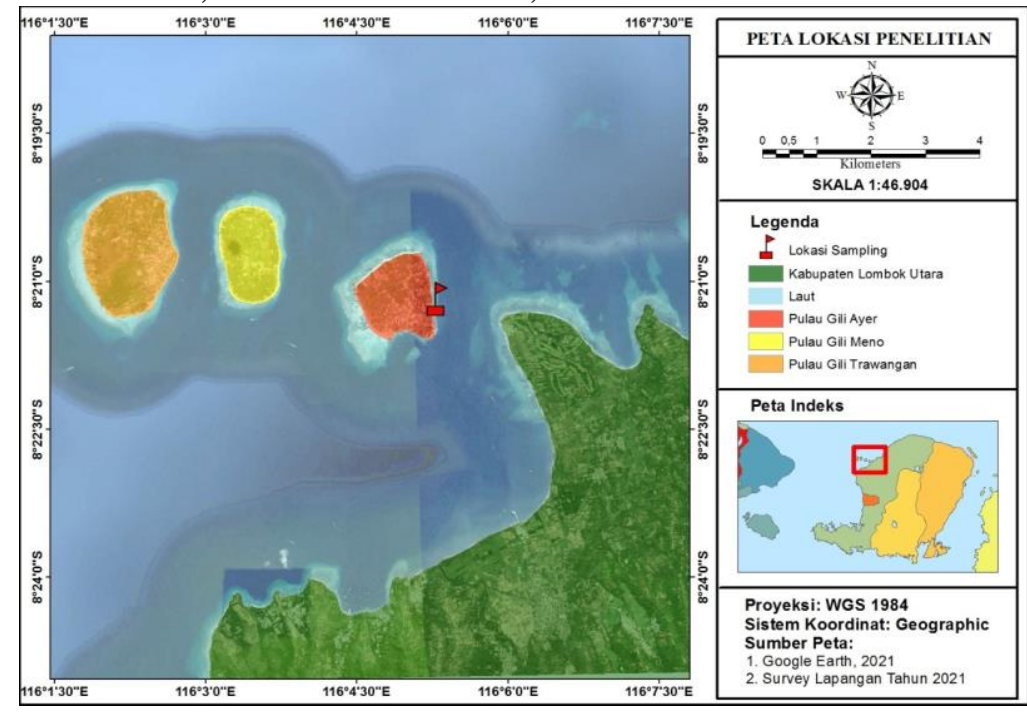

Gambar 1. Peta Lokasi Penelitian 


\section{Metode Pengumpulan Data}

Pengambilan data struktur komunitas lamun dilakukan menggunakan kuadran $50 \mathrm{~cm}$ x50 $\mathrm{cm}$, pada 3 (tiga) stasiun pengamatan dimana masing-masing transek terdapat 4 (empat) titik sampling. Estimasi persentase penutupan lamun dilakukan berdasarkan standar Seagrass Watch (McKenzie et al., 2003). Untuk mengurangi bias, pengambilan data persentase penutupan lamun dilakukan saat kondisi perairan berada dalam keadaan surut rendah. Estimasi penutupan lamun saat kondisi pasang tinggi, relatif lebih sulit dilakukan, karena posisi daun lamun yang berdiri tegak. Selain itu, posisi pengamat menjadi lebih sulit karena harus berada pada jarak yang cukup jauh dari frame kuadran yang diamati. Adapun struktur komunitas lamun yang diamati meliputi: persentase penutupan lamun, penutupan relatif jenis lamun, frekuensi kehadiran lamun, frekuensi kehadiran relatif jenis lamun, dan indeks nilai penting.

\section{Persentase Penutupan Lamun}

Pengamatan persentase penutupan lamun diestimasi berdasarkan monitoring lamun yang ditetapkan oleh Seagrass Net (Short et al., 2015). Penggunaan standar ini sangat penting untuk menghindari bias karena estimasi didasarkan pada pengamatan visual yang bersifat kualitatif atau semi kuantitatif. Persentase penutupan lamun sangat dipengaruhi oleh berbagai faktor seperti jenis lamun, kerapatan lamun dan sebaran lamun.

\section{Persentase Penutupan Relatif Jenis Lamun}

Persentase penutupan relatif jenis lamun dinyatakan sebagai perbandingan penutupan jenis tertentu dengan jumlah total penutupan seluruh jenis lamun yang ditemukan di lokasi penelitian. Adapun persamaan yang digunakan yaitu: $\mathrm{PRi}=(\mathrm{Pi} / \Sigma \mathrm{F})$, dimana: $\mathrm{Fi}=$ penutupan relatif jenis kei; $\mathrm{Pi}=$ penutupan jenis ke-i; dan $\Sigma \mathrm{F}=$ jumlah total penutupan seluruh jenis.

\section{Frekuensi Kehadiran Jenis Lamun}

Frekuensi kehadiran jenis lamun merupakan peluang ditemukannya satu jenis lamun tertentu dalam suatu kuadran contoh dan dibandingkan dengan total jumlah kuadran (Brower et al., 1990). Perhitungan frekuensi kehadiran jenis lamun menggunakan persamaan: $\mathrm{Fi}=\mathrm{Pi} / \Sigma \mathrm{P}$, dimana: $\mathrm{Fi}=$ frekuensi jenis ke-i; $\mathrm{Pi}=$ jumlah kuadran contoh ditemukannya jenis ke-i; dan $\Sigma \mathrm{P}=$ jumlah total kuadran contoh yang diamati.

\section{Frekuensi Kehadiran Relatif Jenis Lamun}

Frekuensi kehadiran relatif jenis lamun dinyatakan sebagai perbandingan frekuensi jenis lamun tertentu dibandingkan dengan jumlah total frekuensi jenis lamun, ditulis dalam persamaan: $\mathrm{FRi}=(\mathrm{Fi} / \Sigma \mathrm{F})$, dimana: $\mathrm{Fi}=$ frekuensi relatif jenis ke-i; $\mathrm{Pi}=$ frekuensi jenis ke-i; dan $\Sigma \mathrm{F}=\mathrm{jumlah}$ total frekuensi seluruh jenis lamun.

\section{Indeks Nilai Penting (INP)}

Indeks nilai penting (INP) diperoleh dari hasil penjumlahan persentase penutupan relatif dan frekuensi relatif dari masing-masing jenis lamun. Indeks ini umumnya dinyatakan sebagai nilai total hasil penjumlahan dalam bentuk persen (\%). Indeks Nilai Penting seringkali digunakan untuk menduga peranan jenis lamun tertentu dalam komunitas. Suatu jenis yang memiliki pengaruh atau peran yang besar dalam komunitas, umumnya memiliki nilai INP yang tinggi. Sebaliknya, jenis yang kurang menonjol dalam komunitas umumnya memiliki nilai INP yang rendah (Brower et al., 1990). Adapun perhitungan nilai INP menggunakan persamaan: INPi = Pri + Fri, dimana: Pri = penutupan relatif jenis ke-i; dan Fri = frekuensi relatif jenis ke-i.

\section{Parameter kualitas perairan}

Parameter kualitas perairan merupakan komponen penting dalam menunjang kelangsungan hidup biota perairan, termasuk tumbuhan lamun. Nilai parameter kualitas perairan yang berada di 
atas ambang batas kisaran baku mutu kualitas air tentunya dapat mengakibatkan terganggunya metabolisme tubuh dan kemampuan adaptasi suatu biota, bahkan dapat mengakibatkan kematian.

Terdapat 7 (tujuh) parameter kualitas perairan yang digunakan untuk mengetahui kondisi kualitas perairan padang lamun Gili Air, yaitu: nitrat $\left(\mathrm{NO}_{3}{ }^{-}\right)$, ammonia $\left(\mathrm{NH}_{3}{ }^{-}\right)$, fosfat $\left(\mathrm{PO}_{4}{ }^{3-}\right)$, kandungan oksigen terlarut (dissolved oxygen/DO), kadar garam (salinitas), derajat keasaman $(\mathrm{pH})$, dan ukuran butir sedimen/substrat. Kelima parameter tersebut diduga berpengaruh terhadap kondisi komunitas padang lamun pada lokasi penelitian.

\section{HASIL DAN PEMBAHASAN}

Komunitas padang lamun di perairan Gili Air termasuk dalam kategori komunitas campuran (mixed community) yang terdiri dari 5 (lima) jenis, yaitu: Halophila ovalis, Thalassia hemperichii, Cymodocea rotundata, Halodulea pinifolia, dan Halodule uninervis. Kelima jenis lamun tersebut ditemukan pada lokasi/stasiun yang berbeda, dimana pada stasiun 1 ditemukan 2 jenis, pada stasiun 2 ditemukan 4 jenis, dan pada stasiun 3 ditemukan 4 jenis, sebagaimana yang ditampilkan pada Tabel 1. berikut:

Tabel 1. Jenis- jenis lamun yang ditemukan pada masing-masing stasiun

\begin{tabular}{llccc}
\hline No & Jenis lamun & Stasiun 1 & Stasiun 2 & Stasiun 3 \\
\hline 1. & Halophila ovalis & - & + & - \\
2. & Thalassia hemprichii & + & + & + \\
3. & Cymodocea rotundata & + & + & + \\
4. & Halodule pinifolia & - & + & + \\
5. & Halodule uninervis & - & - & + \\
\hline
\end{tabular}

Keterangan: (+) ditemukan, (-) tidak ditemukan

\section{Persentase penutupan lamun}

Persentase total penutupan lamun di perairan Gili Air berkisar antara antara 26.88-39.17\%, dan rerata penutupan sebesar 31.53\%. (Gambar 4a.) Menurut Syafrie et al., (2018) persentese penutupan lamun dengan kisaran antara 30 - 59,9 \% tergolong dalam kondisi kurang sehat, sedangkan persentase penutupan lamun pada stasiun 3 sebesar $26.88 \%$ (di bawah 29,9 \%) tergolong dalam kondisi miskin.

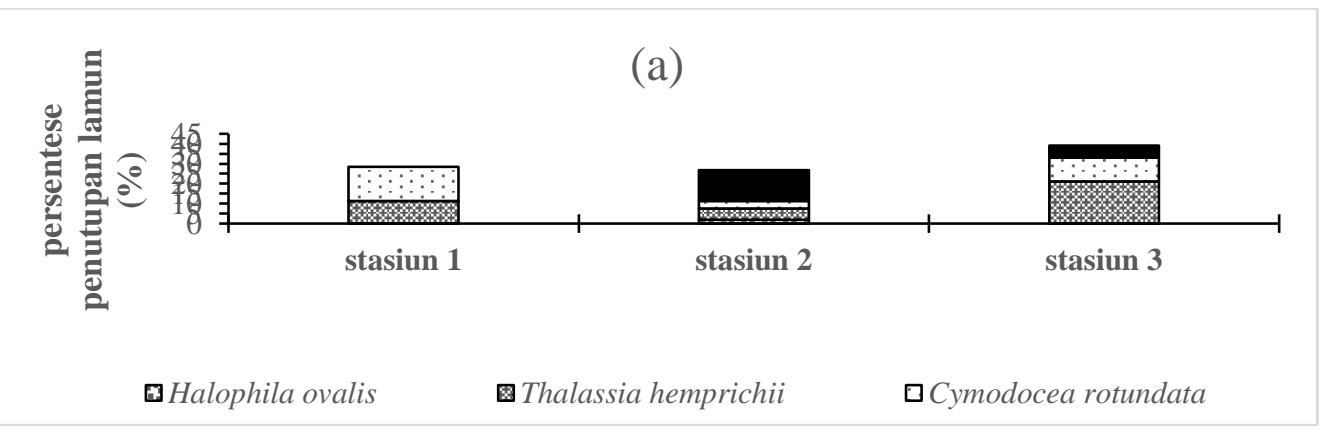




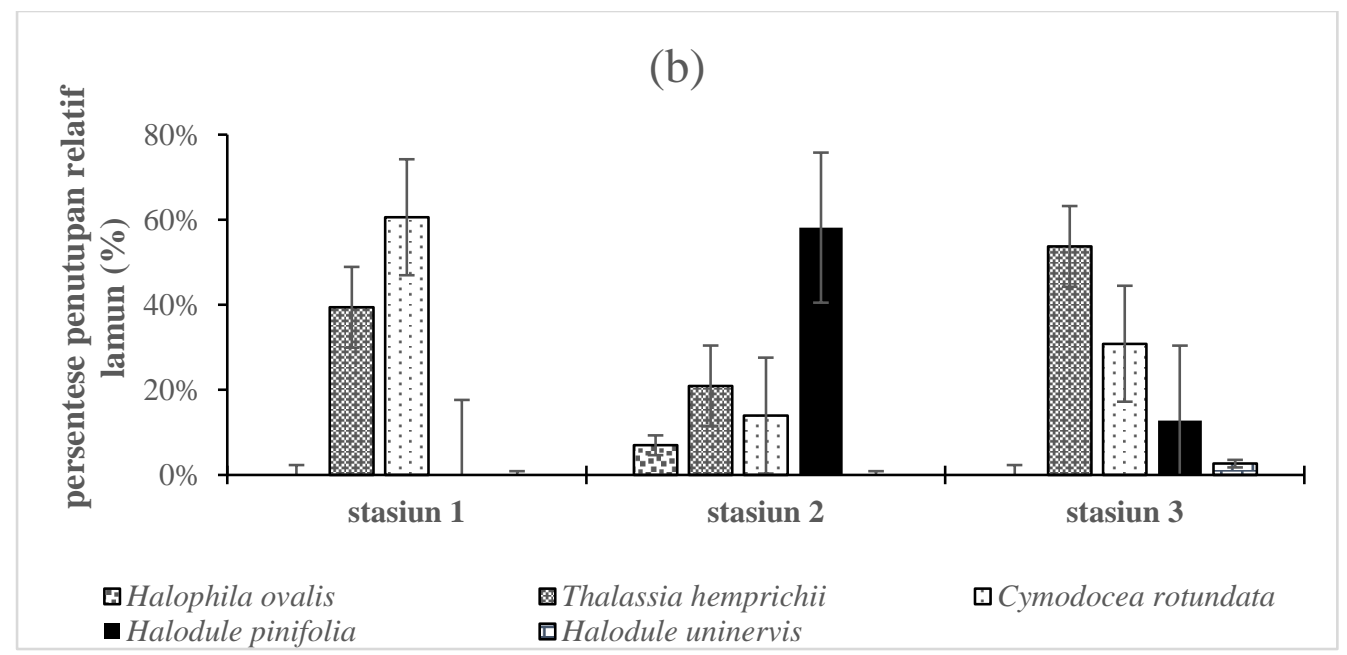

Gambar 2. Persentase penutupan lamun (a), persentase penutupan relatif lamun (b) di Perairan Gili Air

Persentase penutupan relatif jenis lamun (Gambar 2b.) menunjukkan bahwa penutupan jenis lamun Cymodocea rotundata merupakan yang tertinggi pada stasiun 1, dengan nilai penutupan sebesar $61 \%$. Sedangkan jenis yang memiliki penutupan tertinggi pada stasiun 2 dan 3 secara berurutan yaitu: Halodule pinifolia (58\%) dan Thalassia hemprichii (54\%). Rahman, et al. (2021) menjelaskan bahwa perbedaan nilai persentase penutupan lamun pada setiap stasiun penelitian dapat terjadi karena adanya perbedaan kondisi habitat yang mempengaruhi pertumbuhan dan sebaran lamun, serta kemampuan adaptasi yang berbeda antar setiap jenis lamun.

Cymodocea rotundata merupakan jenis lamun yang sesuai dengan kondisi substrat yang berpasir (Rahman et al., 2021). (Ramili et al. (2018) menambahkan bahwa jenis lamun Cymodocea rotundata mampu beradaptasi pada berbagai jenis substrat pada zona intertidal, mulai dari yang bertekstur kasar sampai yang halus. Di samping itu, Cymodocea rotundata merupakan jenis lamun pionir yang memiliki strategi hidup sebagai oportunistik, mampu membentuk koloni dari jenisnya, memiliki cadangan benih tinggi dan dapat pulih dengan cepat dari berbagai tekanan (Kilminster et al., 2015).

Jenis lamun Thalassia hemprichii merupakan jenis lamun cukup dominan di Stasiun 3. Hal ini dikarenakan jenis lamun Thalassia hemprichii memiliki struktur perakaran yang kokoh dan dapat hidup dan beregenerasi dengan baik pada berbagai macam substrat (Rahman, 2016). Sedangkan jenis lamun Halodule pinifolia yang cukup dominan pada stasiun 2, dikarenakan jenis Halodule pinifolia merupakan jenis lamun pionir yang dapat hidup pada kondisi habitat dimana jenis lamunnya tidak dapat tumbuh (Sukandar \& Dewi, 2017).

\section{Frekuensi kehadiran jenis lamun}

Cymodocea rotundata merupakan jenis dengan nilai frekuensi kehadiran tertinggi pada stasiun 1, sebesar 0.67. Pada stasiun 2, jenis lamun Halodule pinifolia memiliki nilai frekuensi kehadiran tertinggi, yaitu berilai 1, yang berarti jenis tersebut selalu ditemukan pada seluruh kuadran pengamatan, atau peluang ditemukannya jenis tersebut adalah $100 \%$. Sedangkan pada stasiun 3, jenis lamun Thalassia hemprichii dan Cymodocea rotundata memiliki nilai frekuensi kehadiran yang sama, yaitu 1 . Sedangkan jenis lamun yang memiliki nilai frekuensi terendah yaitu Halodule uninervis, yang hanya ditemukan pada stasiun 3 dengan nilai frekuensi kehadiran sebesar 0.17 (Gambar 3a). 

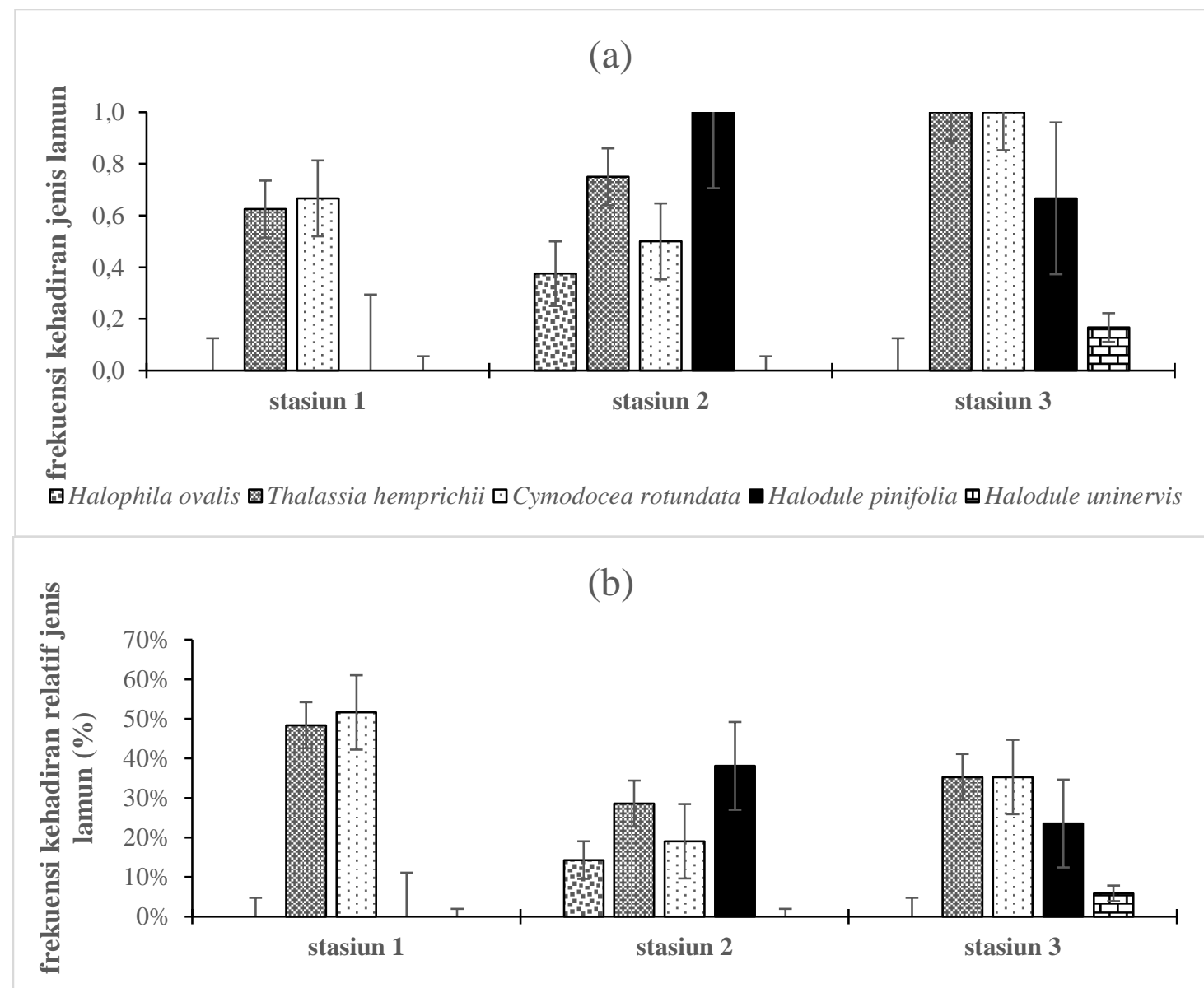

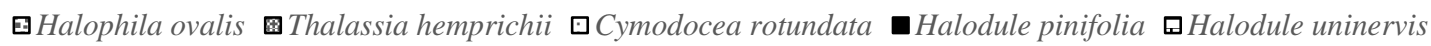

Gambar 3. Frekuensi kehadiran jenis lamun (a); frekuensi kehadiran relatif jenis lamun (b) di Perairan Gili Air

Nilai rerata frekuensi kehadiran relatif jenis lamun pada ketiga stasiun pengamatan memiliki pola sebaran yang serupa. Jenis lamun Cymodocea rotundata merupakan jenis dengan nilai frekuensi kehadiran relatif tertinggi pada stasiun 1, sebesar 52\%. Jenis lamun Halodule pinifolia memiliki nilai frekuensi kehadiran relatif tertinggi pada stasiun 2, sebesar $38 \%$. Sedangkan pada stasiun 3, jenis lamun Thalassia hemprichii dan Cymodocea rotundata memiliki nilai frekuensi kehadiran relatif yang sama, yaitu sebesar 35\% (Gambar 3b). (Rahman, 2016) menyatakan bahwa frekuensi kehadiran lamun menunjukkan derajat penyebaran jenis lamun tertentu dalam komunitas, dimana pola penyebarannya sangat bervariasi dan bergantung pada kondisi lingkungan (Short \& Coles, 2001).

\section{Indeks Nilai Penting}

Indeks nilai penting menggambarkan peranan atau kontribusi suatu jenis lamun dalam suatu komunitas. Berdasarkan grafik indeks nilai penting (Gambar 4), diketahui bahwa jenis Thalassia hemprichii merupakan jenis lamun yang memiliki peranan paling besar dalam komunitas padang lamun Gili Air, dengan nilai sebesar 226\%. Sedangkan jenis Halodule uninervis merupakan jenis lamun yang memiliki kontribusi paling kecil dalam komunitas padang lamun, dengan nilai rata-rata sebesar $9 \%$. 


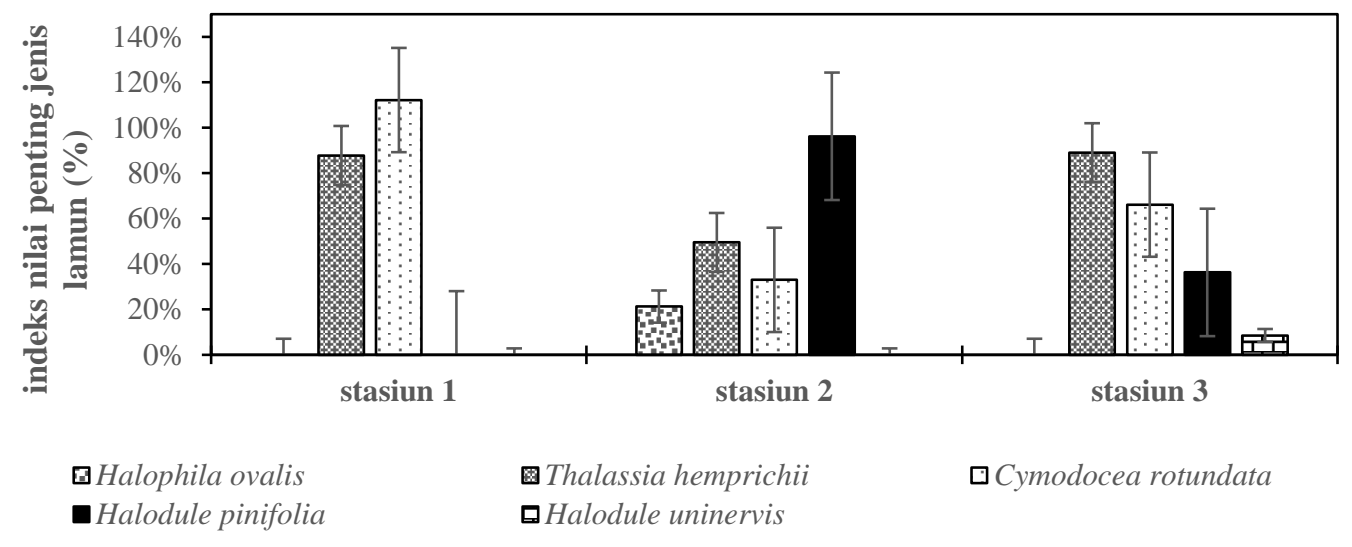

Gambar 4. Indeks nilai penting jenis lamun di Perairan Gili Air

Peranan paling besar yang dimiliki jenis lamun Thalassia hemprichii pada komunitas padang lamun Gili Air dapat terjadi karena kemampuannya dalam beradaptasi pada kondisi habitat perairan Gili Air lebih baik dibandingkan jenis lamun lainnya. Den Hartog (1970) menyatakan bahwa jenis lamun Thalassia hemprichii dapat hidup pada semua jenis substrat, baik berupa pecahan karang, substrat lunak, bahkan pada lumpur cair, tetapi akan menjadi dominan hanya pada substrat keras. Kemampuan beradaptasi pada berbagai jenis substrat tersebut memberikan keuntungan bagi jenis lamun Thalassia hemprichii untuk dapat tumbuh dan berkembang biak dengan baik, sehingga memiliki kontribusi yang paling besar dalam menyusun struktur komunitas padang lamun, khususnya di perairan Gili Air.

\section{Nilai parameter kualitas perairan}

Kisaran nilai parameter kualitas perairan padang lamun Gili Air masih berada di bawah ambang batas standar baku mutu kualitas perairan, kecuali fosfat yang nilainya lebih tinggi dari ambang batas (Tabel 2.).

Tabel 2. Rerata nilai parameter kualitas air

\begin{tabular}{lcccc}
\hline \multirow{2}{*}{\multicolumn{1}{c}{ Parameter }} & \multicolumn{3}{c}{ Stasiun } & \multirow{2}{*}{ Baku Mutu** } \\
\cline { 2 - 4 } & 1 & 2 & 3 & $33-34$ \\
salinitas $(\% 0)$ & 36.7 & 35.7 & 35 & $7-8.5$ \\
pH & 8.1 & 8.1 & 8.1 & $>5$ \\
Oksigen terlarut $(\mathrm{mg} / \mathrm{l})$ & 5.7 & 5.8 & 5.4 & \\
substrat & & & & - \\
pasir $(\%)$ & 96.67 & 98.67 & 90 & - \\
lumpur $(\%)$ & 3.33 & 1.33 & 10 & 0.015 \\
fosfat $\left[\mathrm{PO}_{4}^{3-}\right](\mathrm{mg} / \mathrm{l})$ & $0.13^{*}$ & $0.11^{*}$ & $0.24^{*}$ & 0.06 \\
nitrat $\left[\mathrm{NO}_{3}{ }^{-}\right](\mathrm{mg} / \mathrm{l})$ & $<0.01$ & $<0.01$ & $<0.01$ & 0.3 \\
amonia $\left[\mathrm{NH}_{3}{ }^{-}\right](\mathrm{mg} / \mathrm{l})$ & 0.09 & 0.07 & 0.09 & - \\
klorofil-a $(\mathrm{mg} / \mathrm{l})$ & 0.13 & 0.13 & 0.13 & \\
\hline
\end{tabular}

Keterangan : **Baku mutu: Ambang batas air laut untuk biota laut (PP. No. 22 Tahun 2021). Nilai salinitas dapat bervariasi sampai dengan $5 \%$ dari rata-rata musiman. 
Kandungan senyawa fosfat yang berada di atas nilai baku mutu kualitas air laut pada perairan padang lamun Gili Air disebabkan adanya masukan limbah rumah tangga. Hal ini sebagaimana dinyatakan oleh WHO \& European Commision (2002) bahwa pengkayaan fosfor (fosfat) terutama berasal dari limbah rumah tangga dan industri, termasuk senyawa detergen yang berbahan dasar fosfor. Rahman, (2016) menambahkan bahwa senyawa fosfat yang tinggi mengindikasikan terjadinya proses eutrofikasi sehingga kadar nutrien di perairan cenderung tinggi, dan jika melebihi ambang batas dapat menimbulkan efek toksik bagi biota perairan. Di samping itu, konsentrasi fosfat yang terdekomposisi dalam sedimen dapat terdifusi kembali dan larut ke kolom perairan sehingga menyebabkan kadar fosfat di perairan tersebut meningkat (Paytan \& McLaughlin, 2007).

Nilai konsentrasi fosfat yang cenderung tinggi dan melebihi ambang batas baku mutu kualitas air tersebut diduga memiliki keterkaitan dengan rendahnya persentase penutupan lamun di Gili Air, sehingga kondisi kesehatan lamunnya tergolong kurang sehat dan miskin. Patty et al. (2015) menjelaskan bahwa kandungan fosfat yang tinggi dapat memacu terjadinya eutrofikasi, ditandai dengan adanya ledakan populasi (blooming) fitoplankton yang mengakibatkan perairan menjadi keruh sehingga hal tersebut menghalangi cahaya matahari masuk ke dalam perairan dan mengganggu proses fotosintesis pada lamun. Ketika lamun tidak dapat melakukan fotosintesis dengan optimal, maka kemampuannya untuk beregenerasi akan terhambat, yang berdampak pada kerapatan, penutupan dan kondisi kesehatan lamun.

\section{KESIMPULAN}

Struktur komunitas padang lamun di perairan Gili Air terdiri dari 5 (lima) jenis, yaitu: Halophila ovalis, Thalassia hemperichii, Cymodocea rotundata, Halodulea pinifolia, dan Halodule uninervis, dengan persentase penutupan berkisar antara 26.88\%-39.17\%, dan rerata penutupan sebesar 31,53\%. Kondisi kesehatan lamun di perairan Gili Air termasuk dalam kategori kurang sehat (penutupan antara 30-59,9\%) dan miskin (penutupan <25\%). Jenis lamun Thalassia hemperichii merupakan jenis yang memiliki kontribusi paling tinggi dalam komunitas padang lamun di perairan Gili Air.

\section{DAFTAR PUSTAKA}

Rustam, Agustin., Novi Susetyo Adi, August Daulat, W. K., Deny Suhernawan Yusup, R. A. R., Rustam, A., Adi, N. S., Daulat, A., Kiswara, W., Yusup, D. S., \& Rappe, R. A. (2019). Pedoman pengukuran karbon di ekosistem padang lamun. ITB Press. Bandung.

Rustam, Agustin., Novi Susetyo Adi, R. N. A. A., \& Terry L. Kepel, August Daulat, Mariska A. Kusumaningtyas, Devi D. Suryono, Nasir Sudirman, Aida Heriati, Peter Mangindaan, H. L. S. (2015). Blue Carbon Program inisiatif Blue Carbon Kep. Derawan-Berau Kalimantan Timr.

Brower, J. E., Zar, J. H., \& Von Ende, C. N. (1990). Field and laboratory methods for general ecology. Wm. C. Brown Co. Pub. Dubuque. Iowa.

Den Hartog, C. (1970). The sea-grasses of the world. North-Holland, Amsterdam.

Kenzie, M., Campbell, S. J., \& Roder, C. A. (2003). Seagrasswatch: Manual for mapping \& monitring seagrass resources by community (citizen) volunteers 2 sd edition. In The state of Queensland, Department of Primary Industries, CRC Reef. Queensland.

Kilminster, K., McMahon, K., Waycott, M., Kendrick, G. A., Scanes, P., McKenzie, L., O’Brien, K. R., Lyons, M., Ferguson, A., Maxwell, P., \& others. (2015). Unravelling complexity in seagrass systems for management: Australia as a microcosm. Science of the Total 
Environment, 534, 97-109.

Patty, S. I., Arfah, H., \& Abdul, M. S. (2015). Zat Hara (Fosfat, Nitrat), Oksigen Terlarut dan pH Kaitannya Dengan Kesuburan di Perairan Jikumerasa, Pulau Buru. Jurnal Pesisir Dan Laut Tropis, 3(1), 43. https://doi.org/10.35800/jplt.3.1.2015.9578

Paytan, A., \& McLaughlin, K. (2007). The oceanic phosphorus cycle. Chemical Reviews, 107(2), 563-576.

Peraturan Pemerintah No 22 Tahun 2021 tentang Penyelenggaraan Perlindungan dan Pengelolaan Lingkungan Hidup, 33 (2021).

Rahman, I. (2016). Suitabilty Analysis of Polychaeta Habitat in Seagrass Ecosystem, Parang Island, Karimunjawa, Central Java. AQUASAINS: Jurnal Ilmu Perikanan Dan Sumberdaya Perairan, 4(2), 401-412.

Rahman, I., \& Astriana, B. H. (2019). Penyuluhan Mengenai Ekosisetem Lamun Sebagai Upaya Pelestarian Ekosistem Di Perairan Pantai Sire, Kabupaten Lombok Utara. Abdi Insani, 6(2), 251-258.

Rahman, I., Astriana, B. H., Diniarti, N., Waspodo, S. W., \& Damayanti, A. A. (2020). Pendampingan Masyarakat Dalam Kegiatan Monitoring Sebagai Upaya Pelestarian Ekosistem Lamun Di Perairan Pantai Sire, Kabupaten Lombok Utara. Jurnal PEPADU, 1(4), 497-501.

Rahman, I., Nurliah, Himawan, M., Jefri, E., Damyanti, A., \& Larasati, C. (2021). Keanekaragaman Jenis Lamun Di Perairan Gili Gede, Kabupaten Lombok Barat. Prosiding Seminar Nasional, 10(4), 119.

Rahman, I., Nurliah, N., \& Larasati, C. E. (2021). Efisiensi Teknik Sampling dalam Penentuan Indeks Keanekaragaman Polychaeta di Padang Lamun Pantai Sire, Lombok Utara. Journal of Marine Research, 10(2), 291-298. https://doi.org/10.14710/jmr.v10i2.30533

Rahmawati, S., Irawan, A., Supriyadi, I. H., \& Azkab, M. H. (2014). Panduan Monitoring Padang Lamun (Issue 1).

Ramili, Y., Bengen, D. G., Madduppa, H., \& Kawaroe, M. (2018). Struktur Dan Asosiasi Jenis Lamun Di Perairan Pulau-Pulau Hiri, Ternate, Maitara Dan Tidore, Maluku Utara. Jurnal Ilmu Dan Teknologi Kelautan Tropis, 10(3), 651-665. https://doi.org/10.29244/jitkt.v10i3.22476

Riniatsih, I., Hartati, R., Redjeki, S., \& Endrawati, H. (2018). Studi Keanekaragaman Makrozoobentos Pada Habitat Lamun Hasil Transplantasi dengan Metode Ramah Lingkungan. Jurnal Kelautan Tropis, 21(1), 29. https://doi.org/10.14710/jkt.v21i1.2401

Setiawan, F., Harahap, S. A., Andriani, Y., Hutahaean, A. A. (2012). Deteksi perubahan padang lamun menggunakan teknologi penginderaan jauh dan kaitannya dengan kemampuan menyimpan karbon di Perairan Teluk Banten. Jurnal Perikanan Kelautan, 3(3), 150-154.

Short, F. T., \& Coles, R. G. (2001). Global seagrass research methods. Elsevier.

Short, F. T., Coles, R. G., \& Short, C. M. (2015). SeagrassNet manual for scientific monitoring of seagrass habitat.

Sukandar, S., \& Dewi, C. S. U. (2017). Status padang lamun di Pulau Talago, Madura dan potensinya sebagai bahan baku bioaktif. DEPIK Jurnal Ilmu-Ilmu Perairan, Pesisir Dan Perikanan, 6(2), 138-144.

Syafrie, N. D. M., Hernawan, U. ., Prayudha, B., Supriyadi, I. ., Iswari, M. Y., Rahmat, K., Anggraini, S., Rahmatwati, Suyarso, \& Sjafrie, N. D. M. (2018). Status Padang Lamun Indonesia 2018 Ver.02. In Pusat Penelitian Oseanografi-LIPI (Vol. 53, Issue 9).

WHO \& European Commission. (2002). Eutrophication and Health. Edited by K. Pond. 
Luxembourg: Office for Official Publication of the European Communities. P, 28.

Yunita, R. R., Suryanti, S., \& Latifah, N. (2020). Biodiversitas Echinodermata pada Ekosistem Lamun di Perairan Pulau Karimunjawa, Jepara. Jurnal Kelautan Tropis, 23(1), 47-56. 